\title{
Multi-Criteria Decision Making for Risk Management of Feasibility Phase of Solar Park in India
}

\author{
N Ranganath, Debasis Sarkar, Dhaval Dhaneshwar and Yashdeep Purohit
}

\begin{abstract}
This paper aims at application of Multi-Criteria Decision Making (MCDM) tool like fuzzy VIKOR for decision making process amongst available alternatives for a solar power plant project in India. Here the available three alternatives are "application of both preventive and corrective mitigation measures" which would involve more additional project cost but reduces the project risks in terms of time and cost overrun, "application of preventive mitigation measure", which involves less additional project cost but increases the project risks and "application of corrective mitigation measure", which also involves less additional project cost and increases the project risks. The decision makers considered for this study are client and main contractor respectively. It has been observed from the analysis of this study that after application of fuzzy VIKOR the alternative application of both preventive and corrective mitigation measures would be recommended to the project authorities. The decision makers client and the main contractor need to provide and arrange for the additional funding for implementation of both preventive and corrective mitigation measure so the successful completion of the project within stipulated time and cost frame is enhanced.
\end{abstract}

Keywords - Multi-Criteria Decision Making, Risk management, Feasibility, Solar park.

\section{INTRODUCTION}

Feasibility phase is a vital phase for a solar power plant. The risks faced during the feasibility phase makes may solar plants non-viable. Thereby a detailed risk management is very much required for increasing the viability of the solar power projects. India being an emerging economy, the energy demand is ever increasing. To meet the energy demand India has adopted a policy to boost and promote the renewable

N Ranganath, PhD Student, Pandit Deendayal Petroleum University, Raisan-Gandhinagar, India

Debasis Sarkar, AssociateProfessor \& Former Head of Civil Department, Pandit Deendayal Petroleum University, Raisan-Gandhinagar, India

Dhaval Dhaneshwar, M.Tech Student of Infrastructure Engineering \& Management, Pandit Deendayal Petroleum University, Raisan-Gandhinagar, India

Yashdeep Purohit, M.Tech Student of Infrastructure Engineering \& Management, Pandit Deendayal Petroleum University, Raisan-Gandhinagar, India energy sector. Solar energy sector is one of the major areas which is receiving utmost attention and priority to meet the energy demand in India. Efforts are also being made in India in a huge extent to make the solar power more competitive than the fossil-fuel based energy (Purohit and Purohit, 2010), Purohit et al. (2013). Zarza et al. (2006) presented a conceptual design of the first solar power plant using Direct Steam Generation (DSG) in a parabolic-trough solar field. Aragones-Beltran et al. (2010) made attempt to apply Analytic Network Process (ANP) which is a very popular Multi-Criteria Decision Making (MCDM) tool for selection of solar photovoltaic power plant projects. Jacobson and Delucchi (2011) carried out their research in all renewable energy forms like solar, wind and water. Nithyanandam and Pitchumani (2014) and Dominguez et al. (2012) worked on the cost effectiveness of the solar power plants. MCDM tools applicable to infrastructure projects may also prove quite effective for solar power plant projects. Sarkar and Dutta (2011) applied Expected Value Method (EVM) which proved to be quite effective risk management tool for infrastructure projects like metro rail construction. Sarkar and Singh (2019) applied MCDM tool like Fuzzy Analytical Hierarchy Process (FAHP) for risk analysis of elevated corridor metro rail projects. Sarkar and Singh (2019) compared three MCDM tools to develop risk index for infrastructure projects. Furthermore, Ranganath et al. (2020) applied MCDM tool like Fuzzy TOPSIS to carry out risk analysis of solar power plants. This paper aims at carrying out risk analysis for the feasibility phase of a solar power plant in India by application of MCDM tool like fuzzy VIKOR.

\section{II.CASE STUDY}

The Case Study considered for this research is a solar power plant in Karnataka. This plant is planned by four companies viz. KEPL, MEPL, SEPL\&SAPL at Gaddikere Village near Hagaribommanahalli, Bellary Dist, Karnataka. The capacity of Power Generation of this project is about 12.1 MW (11.0 MW on AC side and 12.1 MW on DC side). The total extent of area comprising all the three survey number works out to be 57.21 Acres. The project was commissioned in the year 2016-17.

The risks identified during the feasibility phase of the solar power project are tabulated in Table 
TABLE: RISKS ASSOCIATED WITH THE FEASIBILITY PHASE OF THE SOLAR POWER PROJECT RISKS IDENTIFIED UNDER PHASE-1(FEASIBILITY STUDIES)

\begin{tabular}{|c|c|c|c|}
\hline No & Activity Risks & No & Sub- Activity Risks \\
\hline \multirow{3}{*}{ (i) } & \multirow{3}{*}{ Problems in Letter of Intent (LOI) } & 1 & Delay in Issue of LOI \\
\hline & & 2 & Wrong Details of Contract \\
\hline & & 3 & Delay in responding to Wrong details by Client \\
\hline \multirow{4}{*}{ (ii) } & \multirow{4}{*}{$\begin{array}{l}\text { Problems in Acceptance and Kick of } \\
\text { Meeting \& Finalization of the Scope and } \\
\text { Deliverables. }\end{array}$} & 4 & Delay in Acceptance of LOI \\
\hline & & 5 & Delay in conducting Kick of Meeting \\
\hline & & 6 & Gaps in scope of work \\
\hline & & 7 & Improper objectives Scope \& Deliverables finalisation \\
\hline \multirow{15}{*}{ (iii) } & \multirow{15}{*}{ Risks in Site location } & 8 & Proximity to International border \\
\hline & & 9 & Proximity to wild life sanctuary \\
\hline & & 10 & Presence of forest land \\
\hline & & 11 & Proximity to eco sensitive zone \\
\hline & & 12 & Proximity to Historical monuments, Place of worship etc. \\
\hline & & 13 & Presence of sensitive lands within the project boundary \\
\hline & & 14 & Highly undulating and rocky terrain. \\
\hline & & 15 & Presence of Built-up Close to Project \\
\hline & & 16 & Access to Site \\
\hline & & 17 & Ground Water Table \\
\hline & & 18 & Impact on Environment \\
\hline & & 19 & Social Impact \\
\hline & & 20 & Availability of Land \\
\hline & & 21 & Permission from Government \\
\hline & & 22 & Presence of low laying area. \\
\hline \multirow{3}{*}{ (iv) } & \multirow{3}{*}{$\begin{array}{l}\text { Problems in Reconnaissance Survey of } \\
\text { Site }\end{array}$} & 23 & Identification of Different Site for Reconnaissance \\
\hline & & 24 & Wrongly Identification of Site Boundary \& Orientation \\
\hline & & 25 & Missing of Key Data during Reconnaissance survey \\
\hline \multirow{2}{*}{ (v) } & \multirow{2}{*}{ Risks in Collection of Data } & 26 & Improper Data Collection \\
\hline & & 27 & Inadequate Data Collection \\
\hline \multirow{4}{*}{ (vi) } & \multirow{4}{*}{$\begin{array}{l}\text { Problems in } \quad \text { Inception } \\
\text { Preparation (IR) \& Submission }\end{array}$} & 28 & Misinterpretation the Scope of Work \\
\hline & & 29 & Defining of Unrealistic Approach \& Methodology \\
\hline & & 30 & Insufficient Time Allocation for Investigation \& Design \\
\hline & & 31 & Delay in Submission of IR \\
\hline \multirow{3}{*}{ (vii) } & \multirow{3}{*}{ Problems in Review and Approval IR } & 32 & Review by non-technical professional \\
\hline & & 33 & Delay in review \& forwarding the observations \\
\hline & & 34 & Delay in approval of IR \\
\hline \multirow{15}{*}{ (viii) } & \multirow{15}{*}{$\begin{array}{l}\text { Risks in Preparation \& Submission of } \\
\text { Draft Feasibility Report (DFR) }\end{array}$} & 35 & Improper Approach \& Methodology for Feasibility Report \\
\hline & & 36 & Insufficient Survey \& Investigation \\
\hline & & 37 & Mistakes in Conducting Survey \& investigations \\
\hline & & 38 & Hydraulic and hydrological Investigations \\
\hline & & 39 & Recommendation of Foundation Type \\
\hline & & 40 & Poor Interpretation of Data \\
\hline & & 41 & Wrong Planning of Master Plan \\
\hline & & 42 & Presence of Utilities \\
\hline & & 43 & Raw Material Sources \\
\hline & & 44 & Preliminary Design \\
\hline & & 45 & Drawings \& Documentation \\
\hline & & 46 & Mistake in Quantity Calculations \\
\hline & & 47 & Adopting Wrong Schedule of Rates for Estimation \\
\hline & & 48 & Delay in Preparation of Draft Feasibility Report \\
\hline & & 49 & Delay in Submission of Draft Feasibility Report \\
\hline \multirow{3}{*}{ (ix) } & \multirow{3}{*}{ Problems in Presentation and Discussion } & 50 & Presenting Wrong Details about Project \\
\hline & & 51 & Discussions of un-related points during presentation \\
\hline & & 52 & Authenticity of Clients Observations \& Incorporation in Report \\
\hline & & 53 & Review by non-technical professional \\
\hline$(\mathrm{x})$ & Problems in Approval of DFR & 54 & Delay in review \& forwarding the observations \\
\hline & & 55 & Delay in approval of DFR \\
\hline & & 56 & Delay in Receiving Comments/Observation of Draft DFR \\
\hline (xi) & Problems in Submission of Final DFR & 57 & Delay in Attending the Comments/Observation of Draft DFR \\
\hline & & 58 & Delay in Submission of Final Feasibility Report \\
\hline
\end{tabular}




\section{CONCEPTUAL FRAMEWORK FOR MCDM TOOL FUZZY VIKOR AND CASE ANALYSIS}

VIKOR method was developed for multi-criteria optimization of complex systems. It determines the compromise ranking list, the compromise solution and the weight stability intervals for preference stability of the compromise solution obtained with the initial (given) weights. VIKOR focuses on ranking and selecting from a set of alternatives in the presence of conflicting criteria.

VIKOR method introduces the ranking index based on the particular measure of "closeness" to the ideal solution by using linear normalization.

\section{A. Steps of this method:}

Step 1:

Identification of objectives of the decision-making process and definition of the problem. Decision making is the process of gathering information and selecting the optimal alternative so as to meet the decision goals. Hence, the primary step is defining the decision goal that in our case is to evaluate and select a favorable agile concept design for implementation. After preliminary screening, three alternatives A1, A2 and A3 are considered for further evaluation.

TABLE : IDENTIFICATION OF THE ALTERNATIVES AND DECISION MAKERS (STEP 1)

\begin{tabular}{|c|c|c|c|c|c|c|c|c|c|c|}
\hline & & \multicolumn{2}{|c|}{ A1 } & \multicolumn{2}{|c|}{ A2 } & \multicolumn{2}{|c|}{ A3 } & \multicolumn{3}{|c|}{ Criteria weightage } \\
\hline & Activities with Risks & DM1 & DM2 & DM1 & DM2 & DM1 & DM2 & A1 & A2 & A3 \\
\hline 1 & Problems in Letter of Intent (LOI) & 3 & 2 & 5 & 6 & 5 & 6 & 3 & 4 & 5 \\
\hline 2 & $\begin{array}{l}\text { Problems in Acceptance and Kick of Meeting } \\
\text { \& Finalization of the Scope and Deliverables. }\end{array}$ & 4 & 3 & 7 & 5 & 9 & 7 & 4 & 5 & 5 \\
\hline
\end{tabular}

Here, A1, A2, A3 are alternatives 1,2 and 3 respectively. Alternative A1 is "application of both preventive and corrective mitigation measures" which would involve more additional project cost but reduces the project risks in terms of time and cost overrun. Alternative A2 is "application of preventive mitigation measure", which involves less additional project cost but increases the project risks. Alternative A3 is "application of corrective mitigation measure", which also involves less additional project cost and increases the project risks. DM1 and DM2 are decision makers 1 and 2 who are client and main contractor respectively. So, in the above table, Decision makers 1 and 2 will give weightage to risks

TABLE : FUZZY RATINGS OF ALTERNATIVES (STEP 3)

\begin{tabular}{|c|c|c|c|c|c|c|c|c|c|}
\hline \multirow[b]{2}{*}{ Activities with Risks } & \multicolumn{2}{|c|}{ Alternative A1 } & \multicolumn{2}{|c|}{ Alternative A2 } & \multicolumn{2}{|c|}{ Alternative A3 } & \multicolumn{3}{|c|}{ Criteria Weightage } \\
\hline & DM1 & DM2 & DM1 & DM2 & DM1 & DM2 & A1 & A2 & A3 \\
\hline Problems in Letter of Intent (LOI) & $\begin{array}{c}(0.1,0.2 \\
0.2,0.3)\end{array}$ & $\begin{array}{c}(0.1,0.2, \\
0.2,0.3)\end{array}$ & $\begin{array}{l}0.4 \\
0.5 \\
0.5 \\
0.6)\end{array}$ & $\begin{array}{l}(0.5,0.6 \\
0.7,0.8)\end{array}$ & $\begin{array}{l}(0.4 \\
0.5 \\
0.5 \\
0.6)\end{array}$ & $\begin{array}{c}(0.5 \\
0.6,0.7 \\
0.8)\end{array}$ & $\begin{array}{l}(0.1 \\
0.2 \\
0.2 \\
0.3)\end{array}$ & $\begin{array}{l}(0.2 \\
0.3,0.4 \\
0.5)\end{array}$ & $\begin{array}{l}(0.4 \\
0.5 \\
0.5 \\
0.6)\end{array}$ \\
\hline $\begin{array}{l}\text { Problems in Acceptance and Kick of } \\
\text { Meeting \& Finalization of the Scope } \\
\text { and Deliverables. }\end{array}$ & $\begin{array}{c}(0.2,0.3 \\
0.4,0.5)\end{array}$ & $\begin{array}{c}(0.1,0.2, \\
0.2,0.3)\end{array}$ & $\begin{array}{l}(0.7 \\
0.8 \\
0.8 \\
0.9)\end{array}$ & $\begin{array}{c}(0.4,0.5 \\
0.5,0.6)\end{array}$ & $\begin{array}{l}(0.8 \\
0.9 \\
1.0 \\
1.0)\end{array}$ & $\begin{array}{l}(0.7 \\
0.8,0.8 \\
0.9)\end{array}$ & $\begin{array}{l}(0.2 \\
0.3 \\
0.4 \\
0.5)\end{array}$ & $\begin{array}{l}(0.4 \\
0.5,0.5 \\
0.6)\end{array}$ & $\begin{array}{l}(0.4 \\
0.5 \\
0.5 \\
0.6)\end{array}$ \\
\hline
\end{tabular}

TABLE : LINGUISTIC VARIABLES FOR TRAPEZOIDAL FUZZY NUMBER (STEP 3)

\begin{tabular}{|c|c|c|c|}
\hline Risk description & Acronym & $\begin{array}{c}\text { Risk } \\
\text { rating }\end{array}$ & Corresponding Fuzzy Number \\
\hline Very poor (VP) & VP & 1 & $(0.0,0.0,0.1,0.2)$ \\
\hline Poor (P) & P & 2 & $(0.1,0.2,0.2,0.3)$ \\
\hline Poor (P) & P & 3 & $(0.1,0.2,0.2,0.3)$ \\
\hline Medium poor (MP) & MP & 4 & $(0.2,0.3,0.4,0.5)$ \\
\hline Fair (F) & F & 5 & $(0.4,0.5,0.5,0.6)$ \\
\hline Medium good (MG) & MG & 6 & $(0.5,0.6,0.7,0.8)$ \\
\hline Good (G) & G & 7 & $(0.7,0.8,0.8,0.9)$ \\
\hline
\end{tabular}




\begin{tabular}{|c|c|c|c|}
\hline Risk description & Acronym & $\begin{array}{c}\text { Risk } \\
\text { rating }\end{array}$ & Corresponding Fuzzy Number \\
\hline Good $(\mathrm{G})$ & $\mathrm{G}$ & 8 & $(0.7,0.8,0.8,0.9)$ \\
\hline Very good $(\mathrm{VG})$ & $\mathrm{VG}$ & 9 & $(0.8,0.9,1.0,1.0)$ \\
\hline
\end{tabular}

Step 4:

The decision makers' judgments are analyzed to get the aggregated fuzzy weight of criteria, and aggregated fuzzy rating of alternatives and a fuzzy decision matrix is constructed. Let the fuzzy rating and importance weight of the kth decision maker be xijk $\{x i j k 1, x i j k 2$, xijk3, xijk4\} and wjk $\{w j k 1, w j k 2, w j k 3$, wjk4 $\}$ where $\mathrm{i}=\{1,2, \ldots, \mathrm{m}\}$ and $\mathrm{j}$ $=\{1,2, \ldots, \mathrm{n}\}$ respectively. Hence, the aggregated fuzzy ratings xij of alternatives with respect to each criterion can be calculated as:

$\mathrm{x}_{\mathrm{ij}}=\left\{\mathrm{x}_{\mathrm{ij}} 1, \mathrm{x}_{\mathrm{ij}} 2, \mathrm{x}_{\mathrm{ij}} 3, \mathrm{x}_{\mathrm{ij}} 4\right\}$

\section{$\mathrm{x}_{\mathrm{ij} 2}=\frac{1}{k} \sum x i j k 2$ \\ $\mathrm{x}_{\mathrm{ij} 3}=\frac{1}{k} \sum x i j k 3$}

$\mathrm{x}_{\mathrm{ij} 4}=\max \left\{\mathrm{x}_{\mathrm{ijk} 4}\right\}$

The aggregated fuzzy weight $\mathrm{w}_{\mathrm{j}}$ of each criterion can be calculated as: $w_{j}=\left\{w_{j} 1, w_{j} 2, w_{j} 3, w_{j} 4\right\}$

where

$\mathrm{w}_{\mathrm{j} 1}=\min \left\{\mathrm{w}_{\mathrm{jk} 1}\right\}$

$\mathrm{w}_{\mathrm{j} 2}=\frac{1}{k} \sum w j k 2$

$\mathrm{w}_{\mathrm{j} 3}=\frac{1}{k} \sum w_{j} k 3$

$\mathrm{w}_{\mathrm{j} 4}=\max \left\{\mathrm{w}_{\mathrm{jk} 4}\right\}$

where

$\mathrm{x}_{\mathrm{ij} 1}=\min \left\{\mathrm{x}_{\mathrm{ijk} 1}\right\}$

TABLE : INDIVIDUAL FUZZY SCORES OF THE DECISION MAKERS AND AGGREGATED SCORES OF ALTERNATIVE A1 (STEP 4)

\begin{tabular}{|c|c|c|c|c|c|c|c|c|c|c|c|c|c|}
\hline \multirow{3}{*}{$\frac{\text { No }}{1}$} & \multirow{3}{*}{$\begin{array}{c}\text { Activities with Risks } \\
\text { Problems in Letter of } \\
\text { Intent (LOI) }\end{array}$} & \multicolumn{4}{|c|}{ Individual scores } & \multicolumn{4}{|c|}{ Individual scores } & \multicolumn{4}{|c|}{ Aggregated scores } \\
\hline & & \multicolumn{4}{|c|}{ DM1 } & \multicolumn{4}{|c|}{ DM2 } & \multicolumn{4}{|c|}{ A1 } \\
\hline & & 0.1 & 0.2 & 0.2 & 0.3 & 0.1 & 0.2 & 0.2 & 0.3 & 0.1 & 0.2 & 0.2 & 0.3 \\
\hline 2 & $\begin{array}{c}\text { Problems in } \\
\text { Acceptance and Kick } \\
\text { of Meeting \& } \\
\text { Finalization of the } \\
\text { Scope and } \\
\text { Deliverables. }\end{array}$ & 0.2 & 0.3 & 0.4 & 0.5 & 0.1 & 0.2 & 0.2 & 0.3 & 0.15 & 0.25 & 0.3 & 0.4 \\
\hline
\end{tabular}

Aggregated scores are averages of corresponding fuzzy scores.

Average of 1 st activity is

$((0.1+0.1) / 2)=0.1$

$((0.2+0.2) / 2)=0.2$

$((0.2+0.2) / 2)=0.2$

$((0.3+0.3) / 2)=0.3$

Average of 2nd activity is

$((0.2+0.1) / 2)=0.15$

$((0.3+0.2) / 2)=0.25$

$((0.4+0.2) / 2)=0.3$

$((0.5+0.3) / 2)=0.4$

Thus, aggregated fuzzy number for 1 st activity for Alternative 1 is $(0.1,0.2,0.2,0.3)$.

Thus, aggregated fuzzy number for 2nd activity for Alternative 1 is $(0.15,0.25,0.3,0.4)$.

Similar steps are repeated for Alternative 2, 3 and criteria weightage.

TABLE : AGGREGATED SCORES OF ALTERNATIVE A1, A2, A3 AND THEIR CRITERIA WEIGHTAGE (STEP 4)

\begin{tabular}{|c|c|c|c|c|}
\hline Weightage & A1 & A2 & A3 & Criteria weightage \\
\hline $\begin{array}{c}\text { Problems in Letter } \\
\text { of Intent (LOI) }\end{array}$ & $(0.1,0.2,0.2,0.3)$ & $(0.45,0.55,0.6,0.7)$ & $(0.45,0.55,0.6,0.7)$ & $(0.23,0.33,0.37,0.47)$ \\
\hline $\begin{array}{c}\text { Problems in } \\
\text { Acceptance and } \\
\text { Kick of Meeting \& } \\
\text { Finalization of the } \\
\begin{array}{c}\text { Scope and } \\
\text { Deliverables. }\end{array}\end{array}$ & $(0.15,0.25,0.3,0.4)$ & $(0.55,0.65,0.65,0.75)$ & $(0.75,0.85,0.9,0.95)$ & $(0.33,0.43,0.47,0.57)$ \\
\end{tabular}


Step 5:

The fuzzy decision matrix is defuzzified and fuzzy weight of each criterion is converted into crisp values using COA defuzzification relation. The crisp values for decision matrix and weight of each criterion are computed.

Defuzzification is done by weighted average of fuzzy numbers.

Fuzzy Corresponding

Number * Criteria weight

$((0.1 * 0.23)+(0.2 * 0.33)+(0.2 * 0.37)+$

$(0.3 * 0.47)) /(0.23+0.33+0.37+0.47)=0.22$

TABLE DEFUZZIFIED VALUES FOR ALTERNATIVE A1, A2, A3

\begin{tabular}{|c|c|c|c|c|c|}
\hline & & $\mathrm{A} 1$ & $\mathrm{~A} 2$ & A3 & Weightage \\
\hline 1 & $\begin{array}{c}\text { Problems in Letter } \\
\text { of Intent (LOI) }\end{array}$ & 0.22 & $\begin{array}{c}0.6 \\
0\end{array}$ & $\begin{array}{c}0.6 \\
0\end{array}$ & 0.37 \\
\hline 2 & $\begin{array}{c}\text { Problems in } \\
\text { Acceptance and } \\
\text { Kick of Meeting \& } \\
\text { Finalization of the } \\
\text { Scope and } \\
\text { Deliverables. }\end{array}$ & 0.29 & $\begin{array}{c}0.6 \\
6\end{array}$ & $\begin{array}{c}0.8 \\
8\end{array}$ & 0.47 \\
\hline
\end{tabular}

Step 6:

Determine the best $f^{*}{ }_{j}$ and the worst $f-{ }_{j}$ values of all criterion ratings, $\mathrm{j}-\{1,2, \ldots, \mathrm{n}\}$. The best and the worst values of all criterion ratings are determined in this step.

For the two activities, Si for activity 2 is

\begin{tabular}{|c|c|c|}
\hline & Problems in Letter of Intent (LOI) & $\begin{array}{c}\text { Problems in Acceptance and Kick of Meeting \& } \\
\text { Finalization of the Scope and Deliverables. }\end{array}$ \\
\hline A1 & 0.22 & 0.29 \\
\hline A2 & 0.60 & 0.66 \\
\hline A3 & 0.60 & 0.88 \\
\hline Weightage & 0.37 & 0.47 \\
\hline
\end{tabular}

\begin{tabular}{|c|c|c|c|}
\hline $\mathbf{f} * \mathbf{j}$ & $\mathbf{0 . 6}$ & $\mathbf{0 . 8 8}$ & Maximum \\
\hline $\mathbf{f - j}$ & 0.22 & 0.29 & Minimum \\
\hline
\end{tabular}

\begin{tabular}{|c|c|c|}
\hline A1 & $\mathbf{0 . 3 7}$ & $\mathbf{0 . 4 6}$ \\
\hline A2 & 0 & 0.17 \\
\hline A3 & 0 & 0 \\
\hline
\end{tabular}

Here A1 in activity 1, i.e. "Problems in Letter of Intent (LOI)" is calculated below

$$
=0.37 *((0.6-0.22) /(0.6-0.22))=0.37
$$

Similarly, A2 in activity 2, i.e. "Problems in Acceptance and Kick of Meeting \& Finalization of the Scope and Deliverables" is

$$
\begin{aligned}
& =0.47 *((0.88-0.66) /(0.47-0.29)) \\
& =0.17
\end{aligned}
$$

Now Ri for A1 is Maximum value in 0.37 and 0.46 , i.e. 0.46 .

Thus, $\mathrm{Ri}=0.46$ $\mathrm{f}^{*}{ }_{\mathrm{j}}$ is the highest in activity 2 , i.e. 0.88

$\mathrm{f}_{\mathrm{j}^{-}}$is the lowest in activity 2, i.e. 0.29.

So,

$\mathrm{S}_{\mathrm{i}}=$ Weightage $*\left(\mathrm{f}^{*}{ }_{\mathrm{j}}-\mathrm{f}_{\mathrm{ij}}\right) /\left(\mathrm{f}^{*}{ }_{\mathrm{j}}-\mathrm{f}_{\mathrm{j}^{-}}\right)$ 


$$
Q_{j}=\frac{v_{j}\left(S_{i}-S^{*}\right)}{S^{-}-S^{*}}+\frac{v_{j}\left(R_{i}-R^{*}\right)}{R^{-}-R^{*}}
$$

where $\mathrm{S}^{*}=\min \mathrm{S}_{\mathrm{i}} ; \mathrm{S}-=\max \mathrm{Si} ; \mathrm{R}^{*} 0 \min \mathrm{R}_{\mathrm{i}} ; \mathrm{R}-0 \max \mathrm{R}_{\mathrm{i}}$ and vis introduced as a weight for the strategy of maximum group utility, whereas $1-\mathrm{v}$ is the weight of the individual target.

The values of $\mathrm{S}, \mathrm{R}$ and $\mathrm{Q}$ are calculated for all concept designs.

Now $\mathrm{v}_{\mathrm{j}}$ is 0.6 and 0.4 .

$\mathrm{S}_{\mathrm{i}}$ for Alternative 1 is $\mathrm{S}_{1}=0.83$

$S_{i}$ for Alternative 2 is $S_{2}=0.17$

$S_{\mathrm{i}}$ for Alternative 3 is $S_{3}=0$

$S^{*}$ is the least amongst $S_{1}, S_{2}$ and $S_{3}$, i.e. 0.83

$\mathrm{S}$ - is the highest amongst $S_{1}, S_{2}$ and $S_{3}$. i.e. 0.17

$R_{i}$ for alternative 1 is $R_{1}=0.46$

$R_{i}$ for alternative 2 is $R_{2}=0.17$

$R_{i}$ for alternative 1 is $R_{1}=0$

$R^{*}$ is the least amongst $R_{1}, R_{2}$ and $R_{3}$, i.e. 0

$R$ - is the highest amongst $R_{1}, R_{2}$ and $R_{3}$. i.e. 0.46

$\mathrm{Q}_{1}=(0.6(0.83-0) / 0.83-0)+(0.4(0.46-0) / 0.46-0)$

$=1$

$\mathrm{Q}_{2}=(0.6(0.17-0) / 0.83-0)+(0.4(0.17-0) / 0.46-0)$

$=0.271$

$\mathrm{Q}_{3}=(0.6(0-0) / 0.83-0)+(0.4(0-0) / 0.46-0)$

$=0$

$\mathrm{Q}$ value for alternative 1 is maximum, hence, alternative 1 should be selected amongst given alternatives.

\section{CONCLUSION}

From the analysis it has been observed that for the feasibility phase of the solar power plant under study it has been observed that amongst the alternatives in which A1 is "application of both preventive and corrective mitigation measures" which would involve more additional project cost but reduces the project risks in terms of time and cost overrun. Alternative A2 is "application of preventive mitigation measure", which involves less additional project cost but increases the project risks. Alternative A3 is "application of corrective mitigation measure", which also involves less additional project cost and increases the project risks. DM1 and DM2 are decision makers 1 and 2 who are client and main contractor respectively. The value of "Q" for alternative A1 is maximum through the fuzzy VIKOR analysis. Thereby though some additional project cost need to be incurred by the project authorities, it would be advisable to incorporate both preventive and corrective mitigation measures. This would reduce the project risks and would enhance the probability of successful completion of the project within stipulated time and cost frame.

\section{REFERENCES}

[1] Aragones-Beltran, P., Chaparro-Gonzalez, F., Pastor-Ferrando, J., Rodrguez Pozo, F. 2010. An ANP-based approach for the selection of photo-voltaic solar power plant investment projects. Renewable and Sustainable Energy Reviews, 14(1), 249-264. https://doi.org/10.1016/j.rser.2009.07.012

[2] Aragones-Beltran, P., Chaparro-Gonzalez, F., Pastor-Ferrando, JP., PlaRubio, A. 2014. An AHP (Analytic Hierarchy Process)/ANP (Analytic Net-Work Process)-based multi-criteria decision approach for the selection of solar-thermal power plant investment projects. Energy, 66, 222-238. https://doi.org/10.1016/j.energy.2013.12.016

[3] Dominguez, R, Baringo, L, Conejo, A. 2012. Optimal offering strategy for a concentrating solar power plant. Applied Energy, 98, 316-325. https://doi.org/10.1016/j.apenergy.2012.03.043

[4] Jacobson, M. Z., Delucchi, M. A, 2011. Providing all global energy with wind, water, and solar power, part I: Technologies, energy resources, quantities and areas of infrastructure, and materials, Energy Policy, 39(3), 1154-1169. https://doi.org/10.1016/j.enpol.2010.11.040

[5] Nithyanandam, K, Pitchumani, R. 2014. Cost and performance analysis of concentrating solar power systems with integrated latent thermal energy storage, Energy, 64, 793-810. https://doi.org/10.1016/j.energy.2013.10.095

[6] Purohit, I., Purohit, P. 2010. Techno-economic evaluation of concentrating solar power generation in India, Energy Policy, 38, 30153029 https://doi.org/10.1016/j.enpol.2010.01.041

[7] Purohit, I., Purohit, P., Shekhar, S. 2013. Evaluating the potential of concentrating solar power generation in Northwestern India, Energy Policy, 62, 157-175 https://doi.org/10.1016/j.enpol.2013.06.069

[8] Ranganath, N, Sarkar, D, Patel, P, Patel, S. (2020) “Application of fuzzy TOPSIS method for risk evaluation in development and implementation of solar park in India" International Journal of Construction Management, 1-11, DOI: 10.1080/15623599.2020.1826027 (published online)

[9] Sarkar, D, Dutta, G. 2011 A Framework for Project Risk Management, for the Underground Corridor Construction of Metro Rail, International Journal of Construction Project Management, 4(1), 21-38.

[10] Sarkar, D, Singh, M. 2019. Development of risk index for mass rapid transit system project in Western India through application of fuzzy analytical hierarchy process (FAHP), International Journal of Construction Management, DOI: 10.1080/15623599.2018.1557997, 114. (Published Online)

[11] Sarkar, D, Singh, M. 2020. Risk analysis by integrated fuzzy expected value method and fuzzy failure mode and effect analysis for an elevated metro rail project of Ahmedabad, India, International Journal of Construction Management, DOI: $10.1080 / 15623599.2020, \quad 1-12$ (Published Online).

[12] Zarza, E, Rojas, ME, Gonzalez, L, Caballero, JM, Rueda, F. 2006. Inditep: The first pre-commercial DSG solar power plant. Solar Energy, 80(10), 1270-1276.

https://doi.org/10.1016/j.solener.2005.04.019 